\title{
Michel Sittow's Maternal Grandfather and His \\ Identification in Medieval Sources
}

\author{
Anu Mänd \\ Tallinn University, School of Humanities, Institute of History, \\ Archaeology and Art History, Uus-Sadama 5, IOI20 Tallinn, \\ anu.mand@tlu.ee

\section{Tapio Salminen} \\ Tampere University, Faculty of Social Sciences, 33014 Tampere \\ University, tapio.t.salminen@tuni.fi
}

\begin{abstract}
In his benchmarking article of 1940 on Michel Sittow, historian Paul Johansen not only discussed the identity of the famous painter, but also surveyed his immediate family and kin, including Michel's maternal grandfather Olef Molner, who had probably arrived to Tallinn from Finland. The authors of this article will take a fresh look at Finnish and Tallinn late medieval sources in order to conduct an in-depth study of Olef Molner's life and activities and assess if Johansen's arguments were solid. The article will also shed new light on how close the socio-economic connections between Finland and Tallinn were in the Middle Ages and how the newcomers became part of various transgenerational networks.
\end{abstract}

Keywords: medieval Livonia; medieval Finland; urban history; social history; medieval merchants; medieval artisans; Michel Sittow; the Molner family

The 2018 exhibition of the paintings of Michel Sittow (ca 1469-I525), which took place at the National Gallery, Washington, and thereafter 
at the Kumu Art Museum, Tallinn, ${ }^{1}$ initiated a new wave of interest in the artist, who was born and died in Tallinn (Ger. Reval). ${ }^{2}$ As widely known, the identity of the painter and his origin from Tallinn were discovered by the historian and archivist Paul Johansen (190I-1965), who published his findings in $1940 .{ }^{3}$ Since then, scholars have predominantly focussed on Sittow's amazing career in European courts and the problems of attribution of the paintings; however, on Sittow's family and his periods of stay in Tallinn, they have largely relied on the information in Johansen's article. ${ }^{4}$ Taking into consideration the amount and variety of late medieval sources in the Tallinn City Archives and the space limits of Johansen's article, it is understandable that he overlooked some sources and that occasionally his assumptions were not grounded. A closer look at the archival sources has therefore revealed new information on Michel Sittow's parents, his family relations and social ties in Tallinn. ${ }^{5}$ This does not mean that the possibilities to discover new evidence on Sittow and his kin are exhausted.

The aim of this article is to discuss the origins and identity of Olef Molner (also Moller), the maternal grandfather of Michel Sittow, who, according to Johansen, was a peasant and small-scale trader from the Raasepori (Swe. Raseborg) area, Finland. ${ }^{6}$ Michel's kin from both paternal and maternal sides are comparatively well documented. While his father, the painter and woodcarver Clawes van der Sittow (d. I482), was most probably an immigrant of Mecklenburgian origin (his surname referring to the village of Zittau near Wismar), his mother Margaretha (d. I5OI) was a daughter of Olef Molner (d. I472), burgher of Tallinn. ${ }^{7}$ This Olef Molner (hereafter referred to as Molner Sr) is not to be

I J. O. Hand, G. Koppel, T.-H. Borchert, A. Mänd, A. van Suchtelen, M. Weniger. Michel Sittow: Estonian Painter at the Courts of Renaissance Europe. National Gallery of Art, Washington; Art Museum of Estonia, Tallinn. Yale University Press, New Haven, 2017.

2 In this article, we use modern place names. The historical German or Swedish equivalent is given in parentheses.

3 P. Johansen. Meister Michel Sittow, Hofmaler der Königin Isabella von Kastilien und Bürger von Reval. - Jahrbuch der Preussischen Kunstsammlungen, 6I. Berlin, I940, I-36.

4 See, for example, J. Trizna. Michel Sittow: Peintre revalais de l'école brugeoise (I468-I525/I526). Centre national de recherches "Primitifs flamands", Bruxelles, 1976; R. Rebas. Der Maler Michel Sittow. Sonderdruck aus Beiträge zur Geschichte der Baltischen Kunst. W. Schmitz, Giessen, 1988; M. Weniger. Sittow, Morros, Juan de Flandes. Drei Maler aus dem Norden am Hof Isabellas von Kastilien. Ludwig, Kiel, 20II, 39-164.

5 A. Mänd. Michel Sittow and Reval (Tallinn): A New Look at Records in the Tallinn City Archives. - Michel Sittow I469-1525: The Artist Connecting Estonia with the Southern Netherlands. Ed. by T. Abel. Art Museum of Estonia, Tallinn, 200I, 3-I3; A. Mänd. Michel Sittowi sotsiaalsed sidemed Tallinnas. - Acta Historica Tallinnensia, 20I8, 24, 24-48; A. Mänd. Naine keskaegses Tallinnas: Michel Sittowi ema. Horisont, 2019, 2, 60-64.

6 P. Johansen. Meister Michel Sittow, 6-7.

7 Ibid., 4-7. 
confused with his homonymic son Olef Molner (hereafter Molner Jr), Margaretha's brother and Michel's uncle, who was last mentioned alive in $1485 .{ }^{\circ}$

Since the focus of Johansen was predominantly on the identity of the artist, he did not devote much space to Michel's relatives, except for the father in whose workshop the future court painter was probably initially trained. Instead, he composed a family tree of the artist, but did not provide it with a list of the sources he had used. ${ }^{9}$ In fact, because of the space limits, Johansen used comparatively few footnotes in the entire article, which makes it difficult to assess if his arguments are solid and his hypotheses correct.

The aim of this article is to take a fresh look at Finnish and Tallinn sources in order to conduct an in-depth study of Olef Molner's life and activities in Tallinn and assess if his origin, Raasepori, can be proven. The article will also shed new light on how close the connections between Finland and Tallinn were in the Middle Ages and how the newcomers were able to establish a successful career and transgenerational family network in the city. In addition to Olef Molner Sr, the activities of his homonymic son will be briefly discussed as well, especially because in some instances it is difficult to ascertain which one of them is referred to in the sources. Michel Sittow's relationships with his mother's sisters, their children, and other alleged relatives and friends of the family have recently been discussed, ${ }^{10}$ therefore they will not be included in this study.

\section{PAUL JOHANSEN AND \\ MICHEL SITTOW'S FINNISH-S WEDISH}

\section{ANCESTRY}

Ever since Paul Johansen's benchmarking article of 1940, Olef Molner $\mathrm{Sr}$ has been regarded as the same person as one Oleff Andersson, who on I5 June I 436 took the oath, paid the fee and was registered as a sworn burgher of Tallinn. ${ }^{11}$ For the following discussion on the identity of

8 Tallinn City Archives (hereafter TLA), 230.I.Aa 35b, fol. 28r. Olef Junior was dead by I489 (ibid., fol. I73r). Archival documents from the town council's collection (230) will be hereafter referred to according to their number only.

9 P. Johansen. Meister Michel Sittow, 6.

Io A. Mänd. Michel Sittowi sotsiaalsed sidemed Tallinnas, 30-3I, 38.

II Das Revaler Bürgerbuch I409-1624. Hrsg. von O. Greiffenhagen. Reval, 1932, I5; P. Johansen. Meister Michel Sittow, 7. See, for example, J. Trizna. Michel Sittow: Peintre revalais de l'école brugeoise, 3; E. Kôks. Michel Sittow: A Painter from Tallinn. - Journal of Baltic Studies I978, 9, I, 33, 41; A. Mänd. Michel Sittow and Reval 
Olef Molner Sr, we find it worthwhile to cite Johansen's reasoning in its entirety here. The section in question comments on the family tree of Michel Sittow. Considering Johansen's wordings on the role of blood and ethnicity in Michel Sittow's ancestry it is to be remembered that the article was published in Germany in 1940 and thus reflects to some extent the contemporary ideological climate of publication. ${ }^{12}$

His [i.e. Clawes van der Sittow's ${ }^{13}$ ] second wife, Michel's mother, was called Margaretha and was the daughter of Oleff Molner, a burgher of Tallinn of Finland-Swedish origin. As so often in colonial towns, women had the crucial role in family relations at that time in Tallinn. Thus, Michel developed firm ties with the Tallinn artisans through his mother's family. For a better understanding a short family tree of Michel Sittow's maternal line is provided here.

The family tree shows vividly what a big role the Swedish element played in blood relations in the artisan class of Tallinn. Master Michel's grandfather from his maternal side is a pure Finland-Swedish, and married - as far as ascertainable - the heiress of another originally Swedish burgher and merchant family residing in Tallinn already in second generation. Starting from these facts it is not difficult, as we will see later, to explain some of Michel's known contacts to Finland and especially to the Raasepori area. The grandfather Oleff Molner, or in Swedish Olaf Andersson Mölnare, is of peasant origin; his father may have been a miller. He trades from Tallinn to North of Sweden (Norrbotten) bypassing Turku [Swe. Åbo] without caring much of the protests of the Swedish castellans. Consequently they confiscated his ship loaded with salt, beer, apples and onions. In Tallinn, too, he is fined several times on illegal pre-emption of rye and fish and even sold war horse to Pskov Russians, which was strongly forbidden. In 1445 he was sentenced to pay a fine for cutting a maidservant's pigtails in Shrovetide feast - in those days a serious trespass of a maiden's honour. This man was evidently a cunning merchant of rough conduct, who could thank his most important assets - among others, the possession of several houses - for skilful but rather devious operations. ${ }^{14}$

In his description of Olaf Andersson, Johansen refers to Michel Sittow's later contacts with Finland and the area of the castle of Raasepori to which he returns in the context of Michel's first sojourn in Tallinn in I507-I4. When discussing the documented commissions of Michel from that period, Johansen states:

(Tallinn), 5; A. Mänd. Michel Sittowi sotsiaalsed sidemed Tallinnas, 25.

I2 For Johansen, see J. Kivimäe. Paul Johansen 1939. aastal. - Tuna: Ajalookultuuri ajakiri 2019, 3, 62-71, 70; J. Kivimäe. Paul Johansen: The Identity of a Historian. - Denmark and Estonia I219-2019: Selected Studies on Common Relations. Ed. by J. E. Olesen. [Universität Greifswald], Greifswald, 2019, 24I-264; J. Kivimäe. Paul Johanseni elu ja töö. - Paul Johansen: Kaugete aegade sära. Ed. by J. Kivimäe. (Eesti môttelugu, 65.) Ilmamaa, Tartu, 2006, 506-52I.

I3 The authors of the article have highlighted key information using bold.

I4 P. Johansen. Meister Michel Sittow, 5, 7. 
Economically the things appear to have been gradually better and better for him [i.e. Michel]; the reputation of his art spread soon in Livonia and to the neighbouring areas. For the parish church in Siuntio [Swe. Sjundeå], which was located in the area of Raasepori where his grandfather Oleff Molner was born, he made "etlike bilde" (wooden sculptures) with which "der kerken altar myt gheczyret vnnd bokledet" [the church altar was decorated and vested], but had to wait long for the payment. ${ }^{15}$

The document Johansen builds his reasoning on is a draft of a letter of the council of Tallinn to an unnamed headman of the castle of Raasepori dated on 30 August I5I5. ${ }^{16}$ Raasepori was built deep in the Finnish archipelago some 90 kilometres north-west of Tallinn in the 1370 and was throughout the days of the Scandinavian Union (I397-I52I) among the most important strategic hubs of the Swedish realm in the Gulf of Finland. Controlling a bailiwick of seven administrational parishes in Western Uusimaa (Swe. Nyland), the castellans had the possibility of surveying, and interfering with, maritime traffic in the less than Ioo kilometre wide mouth of the Gulf of Finland, which gave them a prominent role in the politics of the council of Tallinn in the area. The bailiwick consisted of part of the city's northern hinterland providing not only victuals and building materials but also a work force for the city, such as boatmen, fishers and maid servants, whom Tallinn merchants employed in their households. As almost 200 letters and other testimonies of inheritance from $1350-1560$ indicate the emigration of Uusimaa peasant population to Tallinn was of a considerable level; the number of 'Swedish', i.e. Swedish and Finnish speaking population, from the Finnish southern coast and inland of the city has been estimated to have been II-I2 per cent of the total population in the I53Os. Of all the known Tallinn immigrants from the bailiwick of Raasepori in $1350-1560$ two thirds (66 per cent) were women, apparently younger daughters of peasant shipper and artisan families familiar with the translocal merchant culture and the way of living in merchant households. Evidence also exists

I5 Ibid., 23. Johansen translated bilde as Holzskulpturen, which is certainly correct although the Low German word bild could also refer to a painted picture. However, the latter was in the first half of the sixteenth century usually referred to as gemalet bild or tafel. See A. Mänd. Michel Sittowi sotsiaalsed sidemed Tallinnas, 36, note 93.

I6 Diplomatarium Fennicum: Database of Finnish medieval documents (hereafter DF), no. 6703. Available at: http://df.narc.fi/. The fact that the castellan is in the letter referred to as "her houetman", but in the heading as "der vaghet" implies that even the council knew the Swedish regent Sten Sture the Younger had trusted Raasepori to the custody of Nils Eriksson (Banér) in the winter of $15 \mathrm{I} 4 / \mathrm{I} 5$, the letter was sent to his substitute to act in case Nils was out of the bailiwick. T. Salminen. The Castellans of Raseborg 1373-I558. - New Approaches to the Raseborg Castle. Ed. by J. Harjula, T. Heinonen, M. Holappa, T. Knuutinen. Suomen keskiajan arkeologian seura, Turku (forthcoming). 
of sworn burghers originating from the city of Uusimaa throughout the fourteenth and fifteenth centuries. ${ }^{17}$

A long relationship starting from the late thirteenth century, the free movement of Tallinn merchants and goods on the Finnish coast and the right of local population to sail to trade in Tallinn was secured by charters by local judges and castellans of Turku and Viipuri (Swe. Viborg) in the early fourteenth century. Most of the imports consisted of everyday necessities such as salt and grain, but also cloth, glass and other expensive tableware documented in the seats of the local nobility, vicarages and peasant merchant farmsteads in Uusimaa. ${ }^{18}$

In the letter of 30 August I5I5, the town council of Tallinn writes to the castellan of Raasepori that their burgher Michel the painter (meler) had informed them (wij zint borichtet) that the people of the parish of Siuntio (Szenda) in the castellan's area (gebeyde) had commissioned certain sculptures (bilde) to decorate and vest the church altar, for which he was yet to be paid twenty Riga marks and a barrel of butter. ${ }^{19}$ Since some of the parishioners visiting Tallinn had contradicted this, smeared Michel and maintained that the entire parish had instead agreed with Laurentius, the parish priest of Siuntio, to settle the matter the council asked the castellan to instruct the parishioners and the priest to pay their debt to avoid further costs, and stop smearing Michel in Tallinn. Dated in late August I5I5, the council's letter was written at a time when Michel Sittow himself was not in Tallinn, but on his second period of travelling for commissions in European courts and from where he returned only in I518. Since Michel left Tallinn to the court of King Christian II in the

I7 T. Salminen. The Castellans of Raseborg I373-I558; T. Salminen. Uusmaalaisten Tallinnanperinnöt I350-I560 = Uusimaalaste Tallinna-pärandused I350.-I560. aastal. Padise ja Vantaa: Keskaja sild Padise ja Vantaa vahel = Keskiajan silta Padisen ja Vantaan välillä. Ed. by E. Russow. Padise Vallavalitsus, Vantaan kaupunki ja historiatoimikunta, Tallinn, 20I2, I84-257; T. Salminen. Vantaan ja Helsingin pitäjän keskiaika. Vantaan kaupunki, 20I3, 3II-378. See also G. Kerkkonen. De nyländska Revalsarven under I5ootalet. - Nyländska Studier, 2. (Historiska och Litteraturhistoriska Studier, 24). Svenska Litteratursällskapet i Finland, Helsingfors, 1949, I50, I53; G. Kerkkonen. Finnland natürliches nördliches Hinterland Revals durch Jahrhunderte. - Wirtschaftliche und soziale Strukturen im saekularen Wandel: Festschrift für Wilhelm Abel zum 70. Geburtstag. Bd. 2, Die vorindustrielle Zeit: Außeragrarische Probleme. Hrsg. von I. Bog. Schaper, Hannover, 1974, 518-543; P. Johansen, H. von zur Mühlen. Deutsch und Undeutsch im mittelalterlichen und frühneuzeitlichen Reval. (Ostmitteleuropa in Vergangenheit und Gegenwart, I5.) Böhlau, Köln, Wien, 1973, IOI-IO2.

I8 T. Salminen. Vantaan ja Helsingin pitäjän keskiaika, I22-I23; T. Heinonen. The Social and Material World of Medieval and Early Modern (c. I200-1650) Villages in Southern Finland. (Archaeologia medii aevi finlandiae, XXVIII.) Society of Medieval Arhaeology in Finland, Helsinki 202I, 205-209.

I9 TLA, Aa I4, pag. 49; DF 6703. See also A. Mänd. Michel Sittowi sotsiaalsed sidemed Tallinnas, 36. It is not absolutely certain that the letter concerns Michel Sittow: there was another painter called Michel, active in Tallinn from I488 to I5I8 (A. Mänd, Michel Sittow and Reval, 8). However, the Finnish connections of Sittow's grandfather support the assumption that the Michel meler in the letter was Sittow. 
spring of I514, was in Denmark in the same June, and sailed from there via the Low Countries to Spain in August-September 1515, he appears to have contacted the town council of Tallinn with a letter or an oral message some time in the summer of $1515 .{ }^{20}$ The commission for Siuntio must have taken place during Michel's sojourn in Tallinn from May or June I506 to spring I5I4, very likely towards the end of the period.

As was demonstrated in 200I, Paul Johansen's reasoning in his reconstruction of Michel Sittow's biography is occasionally rather selective and some of the sources he used can be interpreted in more than one way. ${ }^{21}$ An archivist in the Tallinn City Archives since 1924 and the director of the institution from 1934 until his emigration to Germany in 1939, Johansen had a profound knowledge of the material deposited in the City Archives and mastered its textual contents and historical context extremely well. ${ }^{22}$ Such a profound heuristic understanding of the material, however, sometimes resulted in him not listing all the sources in his publications. In his explanatory note for Michel Sittow's family tree, for instance, Johansen comments that he is "not able to provide any sources, because they would break the frames set for the article, and I can only give general reference to the collections of the Tallinn City Archives”. ${ }^{23}$

Occasionally, and as in the case of Michel Sittow's maternal grandfather and his ancestry in the bailiwick of Raasepori and Siuntio, Johansen's wide personal reading of the material appears to have produced circular deductions. Nothing in the letter of 1515 gives any information about the family relations of Olef Molner Sr or Michel Sittow with Siuntio or the bailiwick of Raasepori. Instead, Johansen's identification of Michel's grandfather Olef Molner Sr, active in Tallinn in I442-72 as Olof Andersson active in trade to Norrbotten in the late 1420 , and them being the same as Olef Andersson burgher of Tallinn of 1436 appears to have been based on rather general assumptions; the similarity of names; the successive periods of activity of the three Olofs; the likely Finland-Swedish origin of Olof/Olef Andersson; and the fact that all

20 A. Mänd. Michel Sittow and Reval (Tallinn), 8-9; M. Weniger. Sittow, Morros, Juan de Flandes, 44-46. As far as it is known, no such letter of Michel has survived.

2I A. Mänd. Michel Sittow and Reval (Tallinn), 4.

22 On Johansen, see: BBLd, Johansen, Paul Wulff, Historiker, https://bbld.de/dbbl/358/ (4.IO.202I); J. Kivimäe. Paul Johansen: The Identity of a Historian, 24I-264. On discussion of Johansen's work see also H. Weczerka. Paul Johansen (I9OI-1965), Hanseund Osteuropahistoriker. Bemerkungen zu einer neuen Publikation. - Hansische Gesichtsblätter, 20I2, I3O, 2II-223; A. Selart. Kes ei rajanud Tallinna? Paul Johansen, vôitlus normannismiga ja Eesti ajalugu. - Vana Tallinn 28 (32). Tallinna Linnaarhiiv, Tallinn, 2017, 147-169.

23 P. Johansen. Meister Michel Sittow, 7, note I. 
three resided in Tallinn. As far as we know, not a single document exists where Olef Andersson of 1436 or his namesake of 1428 could be securely identified as Michel's grandfather Olef Molner, nor is there any medieval source on a Tallinn merchant or artisan with the combination of given name Olof, patronym Andersson and surname Molnare or Molner. ${ }^{24}$ To research Michel's maternal ancestry more precisely and to understand Johansen's reconstruction more profoundly, we shall now discuss the sources, identity and whereabouts of the various Olofs in detail.

\section{OLOF/OLEF ANDERSSON}

In medieval and early modern Sweden, as well as in other Nordic countries, the combination of the given name Olof (Olaf, Olef) and the patronym Andersson (son of Anders) was a common set of two Christian names referencing saints and martyrs: Saint Olaf of Norway (d. I03o, canonised II64) and Saint Andrew the Apostle. As a patron of kings and knights and the protector of cattle, St Olaf was also extremely popular in medieval Finland, where his cult in the mid-thirteenth century was comparable to that of the Virgin Mary and was in subsequent centuries present in almost all parish churches and other ecclesiastical institutions in both Finnish and Swedish speaking areas of the region. ${ }^{25}$

A viable example of the popularity of the combination of these two names in Uusimaa is the medieval parish of Helsinga (today approximately the area of Helsinki, Vantaa and Nurmijärvi municipalities), the westernmost parish of the bailiwick of Porvoo (Swe. Borgå) east Raasepori and part of the economic hinterland of Tallinn. In 1545 Olof was the fourth and Anders the seventh most popular given name of the total of 2I8 peasant farmers with farmsteads and households in the parish. In the same year the most popular given name for male peasant farm holders born and baptised around the turn of the sixteenth century was Lars (Laurentius, St Lawrence), the patron saint of the parish church. It is characteristic of fluctuations in naming fashion that a generation earlier between 1507 and 1535 of all the known I 89 patronyms - i.e. the

24 Cf. P. Johansen. Meister Michel Sittow, 7-8.

25 J. Knuutila. Soturi, kuningas, pyhimys: Pyhän Olavin kultti osana kristillustymistä Suomessa I20o-luvun alkupuolelta I5oo-luvun puoliväliin. SKS, Helsinki, 20IO, 384-390, 404-4II. For the cult of St Olaf in medieval Livonia, in particular in Tallinn, see A. Mänd. The Cult and Visual Representation of Scandinavian Saints in Medieval Livonia. - Saints and Sainthood around the Baltic Sea: Identity, Literacy, and Communication in the Middle Ages. Ed. by C. S. Jensen, T. R. Sands, N. H. Petersen, K. V. Jensen, T. M. S. Lehtonen. Western Michigan University, Kalamazoo, 2018, IO2-II9. 
given names of boys born and baptised in around the mid-fifteenth century - the most popular was Olof while Anders was the sixth. In that same period the most frequent given name of adult men in Helsinga was Jöns (St John the Apostle and St John the Baptist), then Lars, Olof, Per (St Peter) and Anders. ${ }^{26}$ In the surviving registers of Hollola härad (Fin. kiblakunta), north of the bailiwick of Porvoo, Olof was the most popular name among the peasant farmers and members of the twelve-man jury in the parish courts with almost 500 occurrences between 1443 and ca I5 $10 .{ }^{27}$

Considering the popularity of the name Olof as evident in the cadastres and other material of Uusimaa and its two bailiwicks of Raasepori and Porvoo, it is not surprising that in Helsinga only at least three Olof Anderssons were active in trade with Tallinn burghers in the first half of the sixteenth century. Of these, Olaf Andersson from the village of Forsby is referred to as a ship owner together with Greger Olsson (Olofsson) of Tikkurila (Swe. Dickursby) between I5I3 and I524, and in I543, a shipper in $1520-24$, and paid tax for selling beer at his premises in 1545 . Located at the mouth of the river Vantaa on the site where the town of Helsinki was established in I550, Olof's farm and activities in Forsby were, between 1540 and I550, taken care by his son Anders Olsson (Olofsson). The habit of naming the eldest son after his grandfather was a common practise in both Swedish-and Finnish-speaking areas in Finland from the Middle Ages to the nineteenth century. The two other Olofs active in the early sixteenth century trade with Tallinn were Olof Andersson of Ylästö (Swe. Övitsböle) some ı kilometres inland, who like his namesake traded with Tallinn merchant Helmich Ficke in the Isios and I520s, and Olof Ruth of Kyrkoby, whose patronym appears to have been Andersson and who sold bast and boards to the castle of Stockholm in $1550 .{ }^{28} \mathrm{~A}$ common combination, Olof Andersson and Anders Olsson also manifested themselves as names among the nobility and burghers in Finland. In Eric Anthoni's comprehensive study (1970) of medieval and sixteenth century nobility, a total of six Olof Anderssons and six Anders Olssons are found, one of them Olof Andersson burgomaster of Turku active between 1498 and I505. Another namesake of his, the burgher Olof Andersson of Turku and contemporary of Olef Molner, was active between I439 and I476. A certain Anders Olofsson is also

26 T. Salminen. Vantaan ja Helsingin pitäjän keskiaika, 382-39I.

27 A. Maliniemi. Olav den hellige, Finland. - Kulturhistoriskt lexikon för nordisk medeltid, I2, 567-568.

28 T. Salminen. Vantaan ja Helsingin pitäjän keskiaika, 334-335, 338, 399-40o. Olof Andersson of Forsby was also probably the Olof Anderson who sat in the twelve-man jury of the parish court in ${ }_{5509}$ (DF 5388 ). 
mentioned as a burgher of Turku between I44I and I447, but as the number and character of the two Christian names in fifteenth-century Finland shows, it is often impossible and even hazardous to build any genealogical link between people. ${ }^{29}$

In early fifteenth-century Tallinn the name Olof Andersson surfaces on several occasions, two of which Paul Johansen concluded were the same person, a man later cited as Olef Molner in the registers and books of memoranda of the council. Earlier specimens of homonymic men of probable Finland-Swedish origin occur at the turn of the fourteenth century. An Olaf Andrisson, who in September 1398 was granted safe conduct in Tallinn until the next Easter, may have been the same Olaf Andirsson van Lasvorn who was then granted a safe conduct for three weeks in September 1399. In June of about 1420, the bailiff of Viipuri Arnt Svensson issued a letter of tovorsichte (attestation) for Anders Clemetsson to collect his late son Olof Andersson's property in Tallinn. Whether or not the same person as the Olaf Andirsson of 1398-99, Anders Clemetsson's son Olof was of an older generation than the Olofs discussed by Johansen. ${ }^{30}$

The Olof Andersson who Johansen regarded as Michel Sittow's maternal grandfather Olef Molner first emerges in the context of a correspondence between the town council of Tallinn and the castellan of Turku Klaus Lydekesson (Djäkn). In a letter dated 26 September 1428 the council tells the castellan that four inhabitants of Tallinn - Laurens Mölner, Toerdii Joensson, Oloff Andraesson and Jacob Laurensson - had in front of the council protested that four weeks ago when they were sailing from Tallinn to Turku, some servants of Klaus had blocked their way near Mustasaari (Swe. Korsholm; in the letter Cryvesholm) and seized their goods. The confiscated property consisted of seven barrels of salt, six barrels of beer, one and a half barrels of apples, a quarter of a barrel of onions and their personal belongings including clothes and Tord Jonsson's sword. In return the castellan had given them four vats of

29 E. Anthoni. Finlands medeltida frälse och I5oo-tals adel. (Svenska Litteratursällskapet i Finland, 442.) Helsingfors, 1970, I42, 377, 398; M. Kallioinen. Kauppias, kaupunki, kruunu. Turun porvariyhteisö ja talouden organisaatio varhaiskeskiajalta I570-luvulle. (Biblioteca historica, 59.) SKS, Helsinki, 2000, 289, 300.

30 Revaler Geleitsbuch-Bruchstücke. Ed. by Paul Johansen. (Publikationen aus dem Revaler Stadtarchiv, 4.) Reval, 1929, no. 893: Olaf Andirsson h. sect a Mychaelis u. pasce (29.09.1398-30.03.1399), no. 920: Olaf Andirsson van Lasvorn a nat. b. virg. u. Mychaelis (8.09.-29.09.1399; also published as DF I623). In his index for the Geleitsbuch-Bruchstücke, pp. 75 and 82, Paul Johansen has identified the two Olaf Andirssons as Anders Clemetsson's son Olof and suggested Lasvorn referring to a place close to Viborg. The toponym is however yet undecipherable. 
Osmund iron, which was not enough to compensate their losses. The council asked the castellan to assist for full return of the seized property. ${ }^{31}$

Six weeks later, on 4 November, the castellan replied to the allegations in response to the council's letter, which Olaff Andersson had presented him. According to Klaus, all accusations were unjust. The company had arrived at the archipelago with other skutes (Ger. Schute, small cargo ships) sailing from Tallinn to Turku, but diverted to the north towards Norrbotten, of which he had heard from those who arrived to Turku. Since this was strictly forbidden both by Swedish law and privileges, he had sent his armed servants to follow them with a kavas (kafuas, a small and fast patrol boat) and bring them to the town hall in Turku. There the magistrates had sentenced them according to the town law to lose everything they had and pay 40 marks each for the trespass. Because of his friendship with Tallinn, the castellan had compensated their fines, returned their ship and given a vat of Osmund iron to each. Should the company have sailed to Turku as normal, he would have helped them to their best advantage. ${ }^{32}$ Very much the same information is repeated in the letter of the council of Turku dated 6 November 1428, where the council informs their colleagues in Tallinn that Klaus Lydekesson had prosecuted four men - Tordhir Jonisson, Olaff Andrisson, Laurencz Moelner and Jeppe Laurenczson - in front of them for an illegal attempt to sail with their merchandise to the new havens in Norrbotten. Since this was against the law of the realm and the privileges of Swedish towns, the magistrate had sentenced them to lose their goods and pay a fee of 40 marks each, after which Klaus had set them free because of their status as inhabitants of Tallinn and as a gesture of friendship to the council. Before leaving, the four men had ascertained in front of the council and Bishop Magnus (II Tavast) of Turku, present at the session, that they had never blamed anyone for being robbed in the incident. ${ }^{33}$

If we consider the names of the four men who shared a ship and aspired to transport salt and beer to the seasonal havens at the river

3I DF 1870. In the letter, the seized property is registered by the four owners as: Int irste Laurens Molner ij thunnen zoltes unde andere klenode; Tordy Joensson ij thunnen zoltes, ij thunnen beyrs unde j swert; Oloff And[r]asson ij thunnen zoltes, ij thunnen beyrs, $i\left[\frac{1}{2}\right]$ thunne appele, j verdendel sypollen unde syne kledere; unde Jacob Laurensson ij thunnen beyrs, $j$ thunne zoltes unde andere have.

32 Klaus Lydekesson's missive has survived both in Swedish original (DF I65I) where Olof Andersson's name is written Olaff Andersson, and in a contemporary Middle Low German translation (DF i874) where the name is written Oleff Andersson. On kavas, see Kavaskorn (Gunvor Kerkkonen). - Kulturhistoriskt lexikon för nordisk medeltid, 8. 2nd edn., 1981. Rosenkilde of Bagger, Denmark, 369.

33 DF 1876 
mouths in the far end of the Gulf of Bothnia to trade them against fish and other products, it is clear that at least two, Tord Jonsson and Olaf Andersson, were of Finnish, Finnish-Swedish or Swedish origin. Since the company was apparently well aware of the route diverging from the Turku archipelago to Norrbotten following the Finnish coast, one of the four men must have sailed it before as far as Korsholm some 300 kilometres north from Turku. A third possible Finnish-Swedish or Finnish name in the company is Jeppe (Jakob) Laurensson, whereas Laurens Molner's surname 'Miller' might tell of German origin. In the surviving draft of the council's letter of September 1428 the name is written by the Tallinn city scribe Johan Muter as Moelner and Molner (with a downward stoke indicating the phoneme oe), and in November by the Middle Low German city scribe of Turku as Moelner. ${ }^{34}$

In all the three missives the four men are stated as being inhabitants of Tallinn (juwe inwonere). Should any of them have been a sworn burgher of the city, the status would have been explicitly stated in the letters because of the nature of the judicial procedure. As visiting merchants resident in Tallinn, the four men were not part of the sworn community of burghers and were very likely to be unmarried men with contacts to each other either previously established or established in the city. Apart from Olof Andersson, who delivered the council's letter to the castellan in person, neither Tord Jonsson nor Jakob Laurensson can be identified in any of the registers of the council or other written material of the city surviving from the first half of the fifteenth century or later. However, of interest is that year after the proceedings in Turku, the council of Tallinn granted one Olef Andersson a safe conduct in the city from about 24 September 1429 to the Easter (I6 April) of I43O. It is very likely that this is the same Olof Andersson still acting as a visiting merchant in Tallinn, he may have entertained compensation for his losses of 1428 in Finland or run into another conflict elsewhere, for which he applied a secure permission for safe sojourn in Tallinn for the winter of I429/30. ${ }^{35}$ Whether he was the same Olef Andersson who on Is June 1436 took the burgher's oath in Tallinn in front of the town councillors, is impossible to establish from the sources.

34 DF 1870. Since both references of his name in the correspondence are found in Middle Low German letters of the councils of Tallinn and Turku, not much proof for his ethnicity can be found on the German word Molner; in the correspondence between Finland and Tallinn personal names or even toponyms written in Swedish were sometimes translated to the Middle Low German without trouble. T. Salminen. Vantaan ja Helsingin pitäjän keskiaika, I3O-I32, 38I.

35 Revaler Geleitsbuch-Bruchstücke, no. I063: Item Oleff Andersson is gel. wente passche. 
Together with Olof Andersson, resident and active in Tallinn between 1428 and I430, the only other member of the company possibly documented in the contemporary sources is Laurens Molner. A merchant resident in Tallinn, but not a burgher, he (laurens moller unser stad jnwaner) appeared in front of the council some time before 9 June I430, when the council wrote a second letter in his favour to the privateer Bartholomeus Voet asking to return him the goods that had been seized from him. Employed as a captain of a free maritime force of several ships and 300 men in the war of Lübeck and the Wendish cities against King Eric (of Pomerania) and the Scandinavian Union since late 1427, Voet was active west of Tallinn in the Gulf of Finland in the sailing season of I430 seizing not only Union vessels but also Hanseatic cargoes arriving and departing Tallinn. One of his prizes was a ship with Moller's goods some time in late May, but neither the destination of the vessel or the quality of Moller's goods is known. ${ }^{36}$ Of legal age in 1428 and I43O, Laurens Moller (Moelner) may have been the same Laurens Molner who is cited as a minor in Hinrik Wickede's resignation of his house to his neighbour Michel Noetke (Notke, Noteke) on 5 November I423. ${ }^{37}$ The fact that both one Olof Andersson and one Laurens Molner took part in the trade in the Gulf of Finland area in the I42Os and had a joint company with two other people in I 428 may have been - together with other circumstantial evidence discussed here later - one of the reasons why Paul Johansen was tempted to build his hypothesis on Olef Molner Senior's identity.

\section{OLEF MOLNER (MOLLER) SENIOR AND JUNIOR}

If not a single source is known to verify the Olof Anderson active between I 428 and I 429 as the same as the Olof Andersson who became burgher of Tallinn in 1436, and them being the same as Michel Sittow's maternal grandfather Olef Molner, how in 1940 did Paul Johansen reach the conclusion that they were one and the same person?

36 Liv-, Est-und Kurländisches Urkundenbuch (hereafter LEKUB). Vol. 8. Hrsg. von H. Hildebrand. J. Deubner. Riga, Moscow, I884, no. 239. On Voet, see Hanserecesse, Abt. I, vol. 8, Hansetage von I426-I430. Duncker \& Humblot, Leipzig, I897, xvii-xviii.

37 Das drittälteste Erbebuch der Stadt Reval I383-I458 (hereafter EB 3). Hrsg. von E. von Nottbeck. (Revaler Stadtbücher, 3). Franz Kluge, Reval, I892, no. 908. 
The first and only year that Johansen cited in connection with the activities of Olef Molner is 1445 (actually I444) in the Tallinn registers of fines (wedde) when an Olef moeller was fined together with eleven others for brewing outside the company. In the same year an Olef moeller was fined for cutting a maid's pigtails at Shrovetide feast. ${ }^{38} \mathrm{~A}$ register of fines, covering the period from about I400 to I52I, contains information on trespasses against city ordinances, public order as well as trading and craft regulations. The three other entries in the registers cited by Johansen in the context of Olef(Andersson) Molner date to I450, when Olef moeller was fined for pre-empting horses for Pskovians, to I453, when Olef moeller is cited two separate times with four others who had illegally pre-empted dried fish, and to 1454 when Olef moeller was fined for trading in grain. ${ }^{39}$ To decide from his footnote in $1940,{ }^{40}$ Johansen also held Olof (Andersson) Molner the same as Olef Molner, to whom the council of Tallinn on I4 January I 458 paid costs of five marks and four shillings on having been sent to the castle of Raasepori. Why the council had sent Olef to Raasepori is not known, but his costs were far more extensive than just delivering letters or messages: only half a year before in June 1457 an unnamed person was paid fourteen shillings (I Riga mark $=36$ shillings) for delivering two letters to Raasepori. Since the new royal headman of Raasepori Eskil Isaksson (Banér) is known to have taken control of the castle in October I457, some four months after the ascension of the new king Christian of Oldenburg, Olef Molner's visit to the castle may have occurred in late 1457 and involved unspecified gifts or dealings, possibly for welcoming the new castellan. From I457 the control of the Finnish areas was much in the hands Eskil Isaksson's kinsman and former regent of Sweden Erik Axelsson (Tott), who at midsummer 1457 had organised a separate election of the new king together with the estates of Finland in Turku and was after that given the control of the castle of Viipuri. ${ }^{41}$

38 TLA, Aa 4a, fol. 44r: Oleff Moller ... disse hebben gebruwen buten der selsscopp. Since Olef's name is crossed out, he apparently had paid his fine ( 3 gulden), but this entry is later amended to: Olff Molner-3 gulden van den keller. On fol. $44 \mathrm{r}$, there are two other entries on him: It. Oleff Moeller I wedde van dar aff dat he der derne de vlechten affsneet to vastellauende. It. Oleff Moller en wedde van 2 kelren de he let vpholden. Johansen (Meister Michel Sittow, 7) has placed the incident of cutting the pigtails to I445, but the right year is 1444 .

39 TLA, Aa 4a, fol. $47 \mathrm{v}$ (I450): It. Oleff Moeller I wedde van dat he den plesscoueren perde heuet vorkofft; fol. 5 or (I453): It. Oleff Moeller (twice!) ... hebben geweddet uan vorkopen van drogen visschen etc.; fol. sir: It. Oleff Moeller I wedde uan kopende er et vppt market kquam.... It. Oleff Moeller I wedde nan kornekope.

40 P. Johansen. Meister Michel Sittow, 7, note 2.

4I P. Johansen. Meister Michel Sittow, 7, note 2; Kämmereibuch der Stadt Reval I432-I463. Bearb. von R. Vogelsang. (Quellen und Darstellungen zur hansischen Geschichte, NF, 22/I-2.) Böhlau, Köln, Wien, 1976, no. 1064, I05I. 
As Paul Johansen suggested in his article, the sources he cited in 1940 were by no means everything available in the Tallinn City Archives. Both in the city books of memoranda and the material of Canute's guild of artisans other entries survive that illuminate the activities of Olef Molner Sr inside and outside of the city. With them a more consistent outline of both his and his son Olef Molner Jr's lives can be created, some of which appears to support Paul Johansen's conclusions of Michel Sittow's maternal ancestry, while some leave it open for further discussion.

In the registers of wedde as well as in the main accounts of the city (Kämmereibuch), other entries exist on Olef Molner from I442 to I457 that Johansen had either missed or left uncited in his article. In 1442 and 1447 an Olef Molner was fined for illegal buying and trading of grain before Christmas, in 1447 also for gambling (van doblende vmme de lotteren) and together with six other merchants for pre-empting grain outside of the barrels in the harbour, i.e. within the limits of the docking area. In 1444 he was among those who had illegally brewed beer outside the company regulations during weeks before Martinmas (II November). In I455 either he or his contemporary, the Tallinn burgher Olef Bekewerter was fined ten marks for trading illegally in rye, whereas in 457 one Jacob, a visiting merchant living at Olef's premises, was fined for pre-emptions outside of the barrels. ${ }^{42}$ Some eleven years later in 1468 Olef Molner was fined for not having his fish inspected and for trading illegally in grain before Christmas, but since Olef Molner Sr died in 1472, this could also have been his son Olef Molner Jr. The son first surfaces in the registers of wedde in 1463 , when he and his servant (Oleff Molners zone und syn junghe) had embarked a Swedish ship before anchoring. ${ }^{43}$ In the main accounts of the city, a Olef Molner is mentioned on 19 October 1454 when he was paid five ferdings (I Riga mark $=4$ ferdings) for cleaning the area in the front of the Karja Gate (vor der Karienporten reine to makende), and on 8 August 1456 when Olef Molner was paid two and a half marks for four barrels of tar. The fourth entry concerning Olef Molner is from I4 March 1478 when Olef

42 TLA, Aa 4a, fol. 42v (I442): It. Oleff Molner I wedde uan korne vor winachten gekofft und vtgerort; fol. 46r (I446): It. Oleff Moeller $j$ wedde van kornekope uor winachten und uan doblende vmme de lotteren. ... It. Oleff Moeller ... ilk en hadde uan kornekoepen uorkopen in der hauene buten den tunne etc.; fol. 43v (I444): It. Oleff Moller ... disse bruweden inder wekene uor sunte mertin vnd sin nicht gescr. inde sellscop; fol. $52 \mathrm{r}$ (1455): It. Oleff Moeller (above: bekerwerter) I wedde uan roggekope Io mr.; fol. $52 \mathrm{v}$ (1456): Jacob myt Oleff Molner I wedde gedan dat he buten den tunne gekopslaget heuet.

43 TLA, Aa 4a, fol. 58r (I468): It. Oleff Molner geweddet dat he synen visch nicht hadde lathen wraken. ... Oleff Molner geweddet dat he korn gekofft hadde vor wynnachten

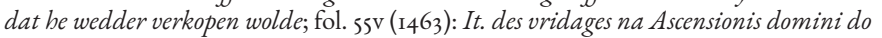
mededen dar vmme dat se yn de Swedeschen schepe stegen weren er de anckere geuellet were Oleff Molners zone vnd syn junghe. 
Molre was paid one mark for two bark ropes (basten tow). Twenty years younger than all the other references to Olef Molner in the main accounts of the council and in the registers of wedde, the entry evidently refers to his son..$^{44}$ Most of the trespasses Olef Molner Sr documented in the register of wedde are of rather a common nature, only the pre-emption of horses to Pskovians and the incident of the maid's pigtails occur as something more extravagant. Neither was he an inveterate violator of city ordinances; rather, the ten occasions he was fined between 1442 and 1457 and the total absence of severe corporal violence may tell us something about a rather decent burgher sometimes tempted to use his trading contacts more effectively than the regulations allowed and occasionally inclined to take extra risks in doing so.

One source, which Johansen did not refer to, but which could perhaps inspire him to make a connection between Olef Molner and Olof Andersson, is the account book of the St Canute's guild from the 1437-1596 period..$^{45}$ Olef Molner is first mentioned there in 1442, when a collection was made among the guild brothers in order to commission a new silver statue of St Canute (Knud): his name is the last on the long list, showing that he had given one ferding for the purpose. ${ }^{46}$ It is not known when he was admitted to the guild; the earliest list of new members has been recorded in the book in the first decade of the sixteenth century. The next reference to Olef Molner survives from I462, but it is not certain if it concerns the father or the son. ${ }^{47}$ The Olef Molner who at the Shrovetide revels (drunke) of I47I was elected assessor (bisitter) of the guild, must have been Olef Jr because his office lasted until the end of the Shrovetide revels of $1474,{ }^{48}$ and his father had died in 1472. Olof Andersson (Olloff Arndesson) is mentioned in the account book only once, in I450, when he was a colvendreger (a kind of master of ceremonies at festivals) at the Shrovetide revels. ${ }^{49}$ In this account book,

44 Kämmereibuch der Stadt Reval I432-I463, no. 960, IO24; Kämmereibuch der Stadt Reval I463-I507. Bearb. von R. Vogelsang. (Quellen und Darstellungen zur hansischen Geschichte, NF, 27/I-2.) Böhlau, Köln, Wien, 1983, no. I640.

45 TLA, 190.I.6o. For this account book, see A. Mänd. Tallinna Kanuti gild ja selle oldermannid keskajal. - Modus vivendi II. Vana Tallinn I6 (20). Estopol, Tallinn, 2005, I32; A. Mänd. Geselligkeit und soziale Karriere in den Revaler Gilden und Schwarzhäupterbruderschaft. - Vereinskultur und Zivilgesellschaft in Nordosteuropa. Regionale Spezifik und europäische Zusammenhänge = Associational Culture and Civil Society in North Eastern Europe. Regional Features and the European Context. Ed. by J. Hackmann. Böhlau, Wien etc., 20I2, 59 .

46 TLA, 190.I.6o, fol. 5 v.

47 TLA, 190.I.6o, fol. I6v.

48 TLA, I90.I.6o, fol. 35r (I47I), 37v (Christmas I473/74), 38r (Shrovetide I474). Olef Molner Jr is last mentioned in the guild book in $\mathrm{I}_{48} 3$, but it is not certain if he was still alive at that time. Ibid., fol. sir: It. noch entfangen $100 \mathrm{mr}$. van Oloff Mollers wegen to den almissen.

49 TLA, 190.I.60, fol. I2r. There were altogether four colvendregers. 
it is sometimes the case that guild brothers are recorded under different names, for instance by their surname and profession. ${ }^{50}$ Therefore, it is theoretically possible that Johansen concluded that one and the same guild member had mainly been referred to as Olef Molner, but once with his patronym as Olof Andersson (I45O), and that the latter was the same person who had sworn the burgher's oath in 1436 . Of course, this is merely a hypothesis.

A brief explanation is needed as to why Olef Molner Sr and his son, who were active in trading, were members of St Canute's guild and not the Great Guild of merchants. The Great Guild, which was the elite guild of the city, consisted predominantly of the more substantial merchants of German origin who were involved in wholesale and long-distance trade. In ${ }_{4423}$, the guild decided that the Krämer (i.e. retail traders, shopkeepers) would no longer be admitted. ${ }^{51}$ St Canute's guild, which in the late medieval period developed into an umbrella organisation of the better crafts (goldsmiths, blacksmiths, tailors, bakers, etc.), had a more diverse membership. Until at least the first quarter of the sixteenth century, $\mathrm{St}$ Canute's guild had a section of merchants (koplude lach) that probably united retail traders and other small-scale merchants, such as Olef Molner Sr and Jr, who were not 'qualified' for the Great Guild..$^{52}$ In addition to social boundaries, ethnic ones were also likely to play a role. ${ }^{53}$

Let us return to the question of the identity of Olef Molner. As we were able to ascertain, in the registers of wedde, the main accounts of the city and the account book of St Canute's guild there is no information on Olef Anderson or Olef Molner in Tallinn before the year I442. Active and resident in the city, on 22 February 1443 Olef Molner Sr bought the former house of Gerd Haverbeke from the two guardians of his unnamed widow. The house was located on the present address of Viru Street I4 (plot 367) between (Hans) Wevelputte's (plot 365) and (Tideke) Bocholt's houses (plot 368). ${ }^{54}$ According to the contract Olef was to buy all Haverbeke's loans before Midsummer of the same year

50 E.g., in I474-75 bisitter Ebbelink van Arenstede and bisitter Ebbelink goltsmit. TLA, 190.I.60, fol. $37 \mathrm{v}-38 \mathrm{r}$.

5I E. von Nottbeck. Die alten Schragen der Grossen Gilde zu Reval. Kluge \& Ströhm, Reval, 1885, 48, art. 7o. See also A. Mänd. Membership and Social Career in Tallinn Merchants' Guilds. - Guilds, Towns, and Cultural Transmission in the North, I300-I500. Ed. by L. Bisgaard, L. B. Mortensen, T. Pettitt. University Press of Southern Denmark, Odense, 2013, 23I.

52 A. Mänd. Geselligkeit und soziale Karriere in den Revaler Gilden, 65.

53 See A. Mänd. Membership and Social Career in Tallinn Merchants' Guilds, 232-235.

54 EB 3, no. I209; L. Tiik. Väljavôttteid Tallinna vanimatest kinnisturaamatutest. Tallinn, 1966-69, MSS in the National Heritage Board and Tallinn City Archives. Vol. 4, Viru tänav 14 (plot no. 367). On Tideke Bockholt, see T. Derrik. Das Bruderbuch der Revaler Tafelgilde (1364-I549). Mikrofiche-Ausgabe. Tectum, Marburg, 2000, 252. 
(24 June I443) and provide the widow a sustension of a separate chamber and a table in the living quarters of the house (dornse) with an annual rent of six marks as long as she lived. Since the house was mortgaged against a total sum of 225 Riga marks with an annual rent of I2 marks, Olef must have trusted his economic prospects during the early years of the Russo-Livonian war of I443-I448. In the war, most of the military activity of the Livonian branch of the Teutonic Order focused on Narva, where troops of Tallinn burghers led by town councillors took part in the town's defense in 1444, the same year Olef was fined twice for illegal brewing. ${ }^{55} \mathrm{~A}$ possible winner of the conflict, Olef soon felt economically secure enough to enlarge his quarters on Viru Street and on 24 September I 445 got permission from the guardians of Tideke Bockholt's estate to build over an older open driveway to his premises with a vaulted passage between his house and Bockholts' wall. Either to finance the extension or for other businesses or his, he then mortgaged his house on 17 December I 445 against a loan of 200 marks from the Hospital of St John with an annual rent of I2 marks. Olef Molner's house on Viru Street is referred to on 17 November 1455, when the house next to Hans Wevelputte's house changed ownership. ${ }^{56}$

The lower city of Tallinn was divided into two parishes - St Nicholas and St Olaf. ${ }^{57}$ Olef Molner's dwelling house at I4 Viru Street was located within the boundaries of the former. There is a good reason to believe that he lived there until his death in 1472 , when his son-in-law Clawes van der Sittow paid for the cost of his funeral and the tolling of the bells in St Nicholas' church. ${ }^{58}$ As a member of the same parish, Clawes may have taken care of the funeral instead of his brother-in-law Olef Jr, who had from at least 1462 been resident in the parish of St Olaf (see below).

55 On the war of $1443-48$ and the Tallinn troops, see J. Kreem. The Town and its Lord: Reval and the Teutonic Order (in the Fifteenth Century). Tallinna Linnaarhiiv, Tallinn, 2002, 70-72, I7I.

56 EB 3, no. 1233, I322; Das Revaler Pergament Rentenbuch 1382-I518. Hrsg. von A. Plaesterer. (Publikationen aus dem Revaler Stadtarchiv, 5.) Revaler Estnische Verlagsgenossenschaft, Reval, I930, no. 92I.

57 For a reconstruction of the city plan and the parishes, see P. Johansen, $\mathrm{H}$. von zur Mühlen. Deutsch und Undeutsch, fig. 3; Tallinna ajalugu, vol. I (I56I. aastani). Ed. by T. Kala. Tallinna Linnaarhiiv, Tallinn, 2019, 88, fig. 75 .

58 TLA, 3I.I.216, fol. 36v: It. entfangen van Clawes meler vor sines wines vader bigraft und dat lude gelt 5 mr.; A. Mänd. Michel Sittowi sotsiaalsed sidemed Tallinnas, 42. 


\section{OLEF MOLNER SENIOR'S CONTACTS WITH SOUTHERN FINLAND}

If we consider the trade and whereabouts of Olef Molner Sr, resident in the city at the latest from 1442 and dead in 1472 , much of his activity bears witness to contacts in Uusimaa. In addition to his visit to the castle of Raasepori in matters of the council in I457, some of the goods he traded in, such as tar and horses, are documented exports of Uusimaa and the bailiwick of Raasepori in the fifteenth century. One of the late medieval tax parcels of the bailiwick of Porvoo in eastern Uusimaa, tar also features significantly in the trade of inland peasant merchants of Helsinga parish with Tallinn burgher Helmich Ficke between I509 and I542. Other exports from the late medieval eastern Uusimaa include tow bark and horses, both goods in the trade of which Olef Sr and Jr were involved in 1453 and $1478 .{ }^{59}$ More intriguingly, an illegal attempt to export horses from the bailiwick of Raasepori to Novgorod Russia is documented as early as in about I420, when the bailiff (Vogt, of the Teutonic Order) of Narva protested against the castellan of Raasepori on the matter. According to the bailiff's letter from an unknown spring in ca 1420 , people from Sweden had in the previous autumn sailed to an island in the Narva river mouth with eight horses and five heads of cattle. Even though the bailiff's servant had strictly forbidden the sale of horses to Russians, the peasants had sailed to the Russian side in the night and sold their horses and cattle there against grain. In Livonia horses were considered war material and their export to Russia was categorically forbidden by the Teutonic Order and other territorial powers. ${ }^{60}$ The ensuing correspondence shows that the peasants and their livestock originated from the bailiwick of Raasepori where horses appear to have been plenty enough to be exported in the early I420s. The peasants had embarked on their enterprise to trade with the Russians with the permission of the castellan of Raasepori, who then complained about the actions of the bailiff of Narva to the council of Tallinn. ${ }^{61}$ Since

59 S. Seppälä. Viljana, nahkoina, kapakalana: Talonpoikien maksamat kruununverot Suomessa v. 1539-1609. SKS, Helsinki, 2009, I72-174; T. Salminen. Vantaan ja Helsingin pitäjän keskiaika, 326-327, 404-405; G. Kerkkonen. Bondesegel på Finska viken: Kustbors handel och sjöfart under medeltid och äldsta Wasatid. Svenska litteratursällskapet i Finland, Helsingfors, 1959, I47-I48, G. Kerkkonen. Helsinge medeltid. (Helsinge sockens historia, I.) [Helsinge], I962, II3-II4.

6o See I. Leimus. Eesti hobune - strateegiline kaup keskajal. - Tuna: Ajalookultuuri ajakiri, 2017, 2, I4-I6.

6I DF 1620: dat overm jare spade im herveste ut Sweden lude gesegelt quemen in de Narwemunde up unsen holm mit achte perden und v koien; DF 1619: dat spade in dem herves mins beren des koninges arme gebur segelden in de Narwe mit ereme quecke und mit anderen erer kopenscap mit minen love und kopslageden mit den Russen, de dar waren. 
Olef Molner Sr was, in 1453, fined for an attempt to pre-empt horses to Pskovians, he may have entertained a possibility of acquiring them from Uusimaa, or more precisely from the bailiwick of Raasepori, but the enterprise failed.

\section{MARITAL RELATIONS OF OLEF MOLNER SR}

According to the family tree, composed by Johansen, Olef Molner Sr was married to a daughter (name unknown) of Jöns Knagge Jr, a burgher of Tallinn, and they had four children: Olef Jr, Margaretha (Michel Sittow's mother), Barbara and Gertrud. ${ }^{62}$

As is often the case with Johansen's constructions, the fact of marriage is not to be found in Tallinn sources. However, there was indeed a connection between Olef and Jöns (in Tallinn sources Jons or Jones). First, they were both members of St Canute's guild and thus part of the same social network. In all likelihood, they entered the guild in about the same time - Jons acted as a steward at Christmas revels I443/44 ${ }^{63}$ and Olaf, as mentioned above, was first recorded in I442. Jons Knagge was last mentioned alive in 1455 , when he witnessed the transfer of Hans Nezeken's house in Ritterstrate to Cord Koruer. ${ }^{64}$ His year of death is not known, but he was dead by the spring of 1466, when Olef Molner sold the house of the late Jones Knagge, located at the Old Market. ${ }^{65}$

This is probably the entry that formed the basis of Johansen's assumption, because the house is described in the source as Olef's inheritance (bouerde). Therefore, it is likely that Olef was indeed the son-in-law of Jons Jr. What the profession of Jons (and his homonymic father) was is not known. Judging from their first name and surname, they were probably of Finnish-Swedish origin (Knagge $=$ peg), where again an intriguing connection to Siuntio and the neighbouring Kirkkonummi (Swe. Kyrkslät) parish can be established. In Siuntio, Knaggeby with its two taxpaying farmers is registered in the cadastres starting from the year 1540. In 156I the village with several others was donated to the

\footnotetext{
62 P. Johansen. Meister Michel Sittow, 6. For Margaretha and Barbara (who was married to the blacksmith Clawes van dem Berge), see A. Mänd. Michel Sittowi sotsiaalsed sidemed Tallinnas, 28-31. Gertrud, who probably remained unmarried, was mentioned in $148 \mathrm{r}$ and I486. TLA, Aa 35b, fol. $238 \mathrm{r}$.

63 TLA, 190.I.6o, fol. $7 \mathrm{r}$ (Jons Knaghe).

64 TLA, Aa 35b, fol. 295r.

65 TLA, Aa 35b, fol. 19or. The record was made on the Friday after Cantate, i.e. on 9 May 1466.
} 
owner of nearby Sjundby manor. Of apparent medieval origin with a central location in what is today the area of Siuntio railway station, alongside the medieval Great Coastal Road between Turku and Viipuri, and not far from Vikträsk with connections to the sea, the village had two medium sized farms in the I540s and I55Os in the possession of Pawel (Paul) Persson and Jons Michelsson. In the cadaster of I550 Jons' patronym is cited as Andersson, but this kind of occasional variation is characteristic of sixteenth-century cadastres. ${ }^{66}$ As early as in 1475 , however, a Jons Knagge is cited as a member of a twelve-man jury in the parish court of Kirkkonummi on the second day after the visitation of Mary (July 3 ) I475, when the district judge Björn Ragvaldsson sentenced several people to fines for false allegations of manslaughter against one Nils Jakobsson of Mavsetco (Medvastö?). ${ }^{67}$ Jons Knagge's status as a member of the twelve-man jury of the parish tells about an articulated position among the taxpaying peasants of Kirkkonummi in I475. His possible place of origin may have been Knaggas in Stor-Kantskog (today Storkanskog), a large village in the Porkkala area with direct access to the Gulf of Finland and only 67 kilometres from Tallinn harbour. ${ }^{68}$

Considering the information of Olef Molner Senior's fatherin-law Tallinn burgher Jons Knagge Jr, dead before spring I466, and his possible identification as a descendant of peasant merchant and/ or shipper families from either Siuntio Knaggesby or Kirkkonummi (Knaggas?), where another Jons Knagge was active as an established position in 1475 , it seems likely that Olef Sr had contacts with Western Uusimaa and the bailiwick of Raasepori not only through his trade in the I440s and I 450 s but also through his wife, a daughter of Jons Knagge Jr. Of this, however, Paul Johansen could not have been aware.

66 For Knaggeby see L. Huldén et al. Knaggeby. Finlandssvenska bebyggelsenamn. Svenska Litteratursällskapet i Finland. https://bebyggelsenamn.sls.fi/. Knaggeby (Siuntio): Finnish National Archives. Suomen Asutuksen yleisluettelo, Siuntio I540-59 and I560-79 (also Gnaggeby); A. Brenner. Sjundeå sockens historia I-II. Hangö, 1953-55, I:283, II:23.

67 TLA, BC 28, fol. 90, Middle Low German translation of the lost Swedish original (DF 6675), TLA, BC 20, fol. I, a vidimation of lagman Jeppe Pedersson on Björn Ragvaldsson's original sentence dated Kyrkeslet on Thursday after Visitation of Mary (July 3), I477. The fact that both the translation of the original sentence and its later visitation were archived in Tallinn tells that a person or persons involved in the case had contacts to Tallinn and saw necessary to clear their name against possible allegations in front of the council. Medvastö is a former island and medieval village in Kirkkonummi coast just opposite Tallinn in the North.

68 Å. Granlund. En västnyländsk namntyp. Folkmålsstudier, Meddelanden från Föreningen för nordisk filologi, I9 (1965). Helsingfors, 68-69; L. Huldén et al., Knaggeby. Finlandssvenska bebyggelsenamn. If Jons Knagge of 1475 was from Knaggas, his name Jons did not live among his descendants: in the second half of the sixteenth century the tax was paid by one Matts Eriksson and his son Matts. U. A. Fleege. Historia. - J. E. Rosberg, U. A. Fleege. Kyrkslätt socken, dess natur, utveckling och historia. Förf, Helsingfors, I9OI, I67. 


\section{OLEF MOLNER JR AND THE HOUSE ON LAI STREET 4I}

As an established member of St Canute's guild, Olef Molner Jr was apparently the Olef Molner who a year later bought himself a house in the parish of St Olaf located on Lai Street just behind the tower of St Olaf's church. The transfer of the house from its former owners Olef Nessen and his unnamed wife was corroborated in front of the council on 13 August I462. ${ }^{69}$ Molner is then cited as the owner of the property in the same November, when the two wardens of St Olaf's church gave Clawes Hoecken a house between Clawes' and Olef Molner's houses to be held with same conditions as the former tenant Hinze Witte had. Located at the present address of Lai 4I (plot no. I6I), Olef Molner Jr's dwelling house and two adjacent smaller estates were part of a complex of three houses (plots no. 16I, I58 and 159) later owned in its entirety by the church of St Olaf and sold after the fire of 1820 as one plot in $1875 .{ }^{70}$ Of the original three, one (no. 158 ) was the property of Olef Moller in 28 April 1477, when he donated it for the use of perpetual alms to the Table guild and St Canute's guild. Olef had got hold of the small house located with a barn on Lai Street next to Henrik ton Orden's house after a just lawsuit and resolution by Lübeck Law. ${ }^{71}$

Possibly caused by problems of health or age (at which the donation of I477 may also hint), Olef Jr transferred his house on Lai Street on 27 September 1479 to his son Hans Moller. The transfer was legally secured in November I480, after a years' process in the town council's court. When Hans took hold of the house it was mortgaged against two loans worth of Ioo and Is marks to the hospitals of St John and Holy Spirit, with the annual rent of seven Riga marks. ${ }^{72}$ In January I482, Olef sealed an open parchment letter in which he left his wife Dorothea her dowry and half of his estate, excluding the price of two lasts of rye (Lübeck last rye $=3,225.6$ litres/netto), from which bread was to be baked for the poor.$^{73}$ He then died some time before 14 October 1489 when his son Hans sold his father Olef Moller's former house on Viru Street I4

69 Viertältestes Erbebuch der Stadt Reval (I458-I48I). Hrsg. von A. Plaesterer (hereafter EB 4). Manuscript in Tallinn City Archives. Tallinn, I936, no. 50.

$70 \quad \mathrm{~EB} 4$, no. 54.

7I LEKUB I3. Hrsg. von M. Mahling, K. Neitmann, M. Thumser. Böhlau, Köln etc., 2018 , no. 547 .

72 TLA, Aa 35b, fol. IO4r; EB 4, no. II2.

73 LEKUB I4. Hrsg. von K. Neitmann, M. Thumser. Böhlau, Köln etc., 2020, no. 483. 
to Lambert Ottink together with a garden outside the Viru Gate and a firewood shed (outside Karja Gate). ${ }^{74}$

Judging by the sources, Olef Molner Jr and his family appear to have moved out of his father's house at the latest in I462, when he bought the estate on Lai Street, after which Olef Molner Sr lived at Viru I4 until his death in I472. After resigning his house at Lai $4 \mathrm{I}$ to his son in 1479-I480, Olef Jr either moved to his father's old house at Viru I4 in his possession, or lived with his son Hans on Lai Street but kept the house on Viru Street in his hands until his death some time before October 1489. During his life Olef Jr had also given out two rather large loans, one of 200 marks to Hans Stanger some time before August I462, when Stanger's former house on Harju Street was transferred to Hans Koppersleger, and one of Ioo marks in April I470, when Henrik Witte mortgaged his house on Pikk Street against that sum to Olaf Molner. Since the latter mortgage was signed to Olef as late as in March I485, he appears to have been still alive. ${ }^{75}$ Of interest is that, like his father, Olef Molner Jr appears to have had contacts with merchants operating between Finland and Tallinn. On 26 June 1483 the castellan of Viipuri Laurens Axelson (Tott) wrote to Tallinn from Viipuri that the lady Birgitta (thenna danne quinna bustrv Birgitta) who would present the letter to the council had told him that after the death of her husband some years ago in Tallinn, Oleff Mollare had seized and sold the ship he had left there without her husband being in any debt to Olef. ${ }^{76}$

Considering Hans Molner's decision to sell his grandfather's house on Viru Street in I489, it is worth noting that between July I48I and 6 September 1489 he had mortgaged his house at Lai $4 \mathrm{I}$ against four different loans with a total of 550 marks and annual rent of 29 Riga marks. ${ }^{77}$ Only two months after Hans Moller's last mortgage of the Lai 4I house against a loan of 200 marks from Tallinn burgher Hinrick Holtappel, and some two weeks after Hans Moller had sold his grandfather's house at Viru i4, Hinrick Holtappel bought himself almost half of the loans (250 marks) from other creditors and, finally, all the rest except that of the hospital of St John in September $1490 .{ }^{78}$ After

74 TLA, Aa 35b, fol. I73r: Hans Moller ... vorleth Lamberth Ottinge synes vaders inwonlike erue belegen in den Lemstrate tusschen here Reynolt van Werden vnnde Hans Hesteden buszern mit eynen garden vnd schunen buten der Lemporten tusschen her Reynolt van Werden vnnde Bernd Cleners garden vnnd eyn holtrumme tusschen bere Johann Boyszmanns vnd Hinrik Kosters holtrumme.

75 DF 3834 ; LEKUB I4, no. 384.

76 LEKUB I4, no. 6Io (= DF 392I).

77 TLA, Aa 35b, fol. I04r.

78 TLA, Aa 35b, fol. I04r (30.I0.I489). Hinrick Holtappel was a merchant of Westphalian origin, a brother of the goldsmith Hans Holtappel. A. Mänd. Hans Holtappel, 
Hans died some time before 1497, his widow Ramborg mortgaged the house at Lai 4I against a loan of further 300 from a hospital close to the Nunna gate, and finally let her new husband Michel Swabbert transfer the house to Hinrick Holtappel on is December 1503 against an annual rent of 22 marks, which Holtappel paid to Ramborg. ${ }^{79} \mathrm{~A}$ Swedish name documented in Uusimaa contexts in Tallinn in the mid-fifteenth century, Hans Moller's wife very likely originated from the area. ${ }^{80}$

\section{HANS MOLNER (MOLLER)}

In order to demonstrate the transgenerational continuation of the family and traditions of following the profession of one's father, it is necessary to say a few words about Hans Molner (Moller), the son of Olef Jr and a grandson of Olef Sr. The tracing of his activities in late medieval sources is to some extent problematic because there were at least three, if not four, men bearing that name active in the city of Tallinn from the late I460s and I470s. The 'first' Hans Moller was admitted to the Table guild (a charitable sub-organisation of the Great Guild), the second became a member of the Table guild in 1470 , and one of them was commemorated at Easter $1496 .{ }^{81}$ One of them, probably the 'first', took the burgher's oath on 18 September $1467 .{ }^{82}$ In the lists of the Brotherhood of the Black Heads, a Hans Moller or Molner occurs in 1453 , from Shrovetide revels of I463 to Christmas I465/66, from Shrovetide 1467 to Christmas of the same year, from Shrovetide 1469 to Shrovetide I470, and at Shrovetide $1482 .{ }^{83}$ It is likely that the 'first' Hans, who was admitted to the Table Guild in 1465 , participated in the festivals of the Black Heads from 1463 to 1465 (and possibly in I453), the 'second' from I465/66 to I470 and the 'third' in 1482 .

However, none of these Hans Mollers who belonged to the merchants' associations was identical to Olef's son, who, just like his father and grandfather, was a member of St Canute's guild: he acted as a steward

kullassepp. - T. Kala, J. Kreem, A. Mänd. Kümme keskaegset tallinlast. Varrak,

Tallinn, 2006, I04.

79 TLA, Aa 35b, fol. I04r.

80 T. Salminen. Vantaan ja Helsingin pitäjän keskiaika, 393, 599 (Appendix 3, A4).

8I TLA, I9I.2.I, fol. 3Ir (I465), 35r (I470), 49r (I496). See also T. Derrik. Das Bruderbuch der Revaler Tafelgilde, $376,380,395$.

82 Das Revaler Bürgerbuch $1409-1624,26$.

83 TLA, 87.I.2O, pag. 39 (I453), II4 (I463), II9, I2I, I25, I29 (I465/66), I4O (I467), I 43 (I467/68), I53 (I469), I57, I63 (I470), 250 (I482). Another Hans Moller was a Black Head from I506 to 1523 (TLA, 87.I.2Ia, pag. 38, I5I) and admitted to the Great Guild at Christmas revels of I523/25 (TLA, 191.2.15, pag. I34). 
at the Christmas revels of $1472 / 73$ - a task usually assigned to junior members of the guild. ${ }^{84}$ What makes it difficult to distinguish between the various Hans Mollers is that in addition to similar names they all seem to have been involved in shipping and trading.

An apparent burgher of Tallinn, one Hans Mollener is mentioned as one of the three executors of the will of Mattis Muel in November 1473. ${ }^{85}$ Whether or not the same Hans Moller as the homonymic brotherin-law of Laurens Borstel, who in July 1473 is cited as a lender in the context of the transfer of a house on Lai Street between Laurens and his brother Georg, a burgher and shipper Hans Moller was asked together with another shipper in 1474 to investigate the quality of salt shipped into Tallinn from Lübeck by Jakob Kadevolt, and is then given in December I474 two letters of tovorsichte of the council to sue his creditor in Gdańsk (Ger. Danzig) and to get his ship out of unjust blockade in Köningsberg (today Kaliningrad). ${ }^{86}$ Hans Molre, a servant of Laurens Axelsson (Tott) headman of Raasepori from 1468 and thereafter also Viipuri until his death in 1483 , is documented in September and October I48I. Active in trade, Hans had run into conflict with Tallinn councillors Hinrick Schelewent and Hemming (Hennink) Rumor and burgher Hans Bockholt, for which Laurens asked the council to support Hans with his appellation to Lübeck. Hans had been first prosecuted in Tallinn for a guardianship he had proclaimed to have in the city, but after an application to Lübeck he had been sentenced to leave the house and loose the goods he had tried to usurp. ${ }^{87}$ In April 1482 the council further wrote Laurens a safe conduct they had given on his request to Hans Molre to come and settle his dispute with Tallinn burghers Merten Bocklem and Kort Vincke. ${ }^{88}$ Apparently not a burgher, but a servant of Laurent Axelsson, temporary resident in Tallinn, Hans Molre of I480-I483 was not the same person as Hans Molner, Olef's son.

These are but few examples of the occurrences of various Hans Mollers in the sources. However, since Olef Molner's grandson is not the focus of this study, we will not pursue this line of enquiry further.

84 TLA, 190.I.6o, fol. 36v. Each major annual festival of the guild was organised by two stewards (gerdelude).

85 LEKUB I3, no. I82.

86 LEKUB I3, no. 202, 285, 286.

87 LEKUB I3, no. 384 ; LEKUB I4, no. 416.

88 DF 3912 . Merten Bocklem (Bokelem) was admitted to the Table Guild at Christmas I472/73 and took the burgher's oath on 6 August I473. TLA, I9I.2.I, fol. 37r;

Das Revaler Bürgerbuch, 3I. 


\section{CONCLUSION}

Although a thorough examination of fifteenth-century sources enabled us to discover several new facts about the life and career of Sittow's grandfather Olef Molner, it turned out that it is impossible to find any evidence that he was identical to the Olaf Andersson who became burgher of Tallinn in I436. Therefore, it is very likely that Johansen's construction of Olaf Andersson mölnare (Molner) is nothing but an assumption.

Olef Molner, who features in the sources of Tallinn from I442 to his death in 1472 , had close trading contacts with the western Uusimaa region, and apparently married a woman with possible contacts to the Siuntio and Kirkkonummi areas, all of which can, but does not necessarily have to, mean that Molner originated from southern Finland. He was active in trading, but, as other non-German and small-scale merchants, he belonged to St Canute's guild, which predominantly consisted of artisans, and not to the Great Guild, which united the German-speaking elite of the city. The fact that Olef was a house-owner, indicates that he was a wealthy man and thus his business must have gone well. His only son followed the father's footsteps: he too was active in trading and a member of St Canute's guild. In social terms, the career of Olef Jr was more successful than that of his father - he was elected as one of the two assessors of the guild. Both Olefs (as well as Olef Junior's son Hans) were involved in trade and shipping, a combination that was still comparatively widespread in the fifteenth century but became rarer in the following century when the social boundaries between merchants and craftsmen became defined more clearly.

What our study hopefully also demonstrated is that there is a great potential in the investigation of economic, social and cultural contacts between Livonia (especially Tallinn) and Finland in the medieval and early modern period. Close personal relations, based on transgenerational family ties or trade, deserve to be examined in detail as well. The combination of sources from both shores of the Gulf of Finland enable scholars to gain much more information, in quantitative and qualitative terms, than would be possible by relying only on the materials available in each state. 


\section{Acknowledgements}

This preparation of this article has been supported by Estonian Research Council grant PRG1276, Tallinn University grant TFi620, and a grant from the Finnish Cultural Foundation for research on medieval material relating to Raseborg castle (2018).

\section{MICHEL SITTOWI EMAPOOLNE VANAISA JA TEMA TUVASTAMINE KESKAEGSETES ALLIKATES}

\section{Anu Mänd, Tapio Salminen}

Paul Johansen, kes 1940. aastal avaldas põhjaliku artikli Michel Sittowi kohta, tegeles selles kirjatöös mitte üksnes kuulsa maalikunstniku eluloo rekonstrueerimisega, vaid visandas ka tema sugupuu. Johanseni väitel oli Sittowi emapoolseks vanaisaks soomerootsi päritolu talupoja soost väikekaubitseja Olaf Andersson Mölnare ehk alamsaksapäraselt Molner, kes oli sündinud kusagil Raasepori piirkonnas. Kuna Johanseni artiklis leidub viiteid minimaalselt ja seal ei kajastu kôik kasutatud allikad, on paljude tema arutluskäikude ja järelduste kontrollimine väga raske. Nagu viimase aastakümne uurimustest Sittowi Tallinna-perioodide kohta on selgunud, ei pea nii mõnedki Johanseni artiklis esitatud järeldused paika.

Artiklis analüüsitakse põhjalikult Soome ja Tallinna hiliskeskaegseid arhiiviallikaid, eesmärgiga välja selgitada, millel pôhines Johanseni arvamus, et Olef Molneri nimeline Tallinna kodanik, kes suri I472. aastal ja oli vaieldamatult isaks Margaretha Molnerile (Michel Sittowi ema), on identne 1436. aastal kodanikuvande andnud Olaf Anderssoniga. Laiem eesmärk on süvitsi uurida Olef Molneri ja tema samanimelise poja tegevuse kajastumist allikates ning iseäranis vanema Olefi vôimalikke kontakte Lóuna-Soomega.

Teadaolevalt ei ole säilinud ühtegi allikat, kus Sittowi vanaisa nimi esineks kujul Olaf Andersson Mölnare vôi Olaf Andersson Molner isa- ja liignime (perenime) koosesinemist tolleaegsetes dokumentides ei praktiseeritud. Samuti ei ole mingeid tôendeid selle kohta, et Tallinnas tegutsenud Olaf Andersson ja Olef Molner vanem olnuks üks ja sama inimene. Olaf Andersson oli Soomes (ja Rootsis) väga levinud nimi, mistôttu on äärmiselt raske kindlaks teha, milline neist oli saabunud Tallinna ja andnud I436. aastal kodanikuvande. Ühte kaubitsemisega tegelenud Olof Anderssoni on mainitud Tallinna rae ja Turu linnuseülema 
I420. aastate lốpu kirjavahetuses, ent pole vôimalik kindlaks teha, kas tegu on sama mehega, kes andis kodanikuvande.

Sittowi vanaisa Olef Molner on Tallinna allikates jälgitav aastatel I442-I472. Tegemist oli väikekaupmehega, kes oma tegevushaarde ja mittesaksa päritolu tôttu kuulus Kanuti gildi ning kes omas maja Viru tänaval (Viru I4). Molneril olid tihedad kaubakontaktid Uusimaa maakonnaga ja ta abiellus naisega, kelle perekonnal oli tôenäoliselt sidemeid Siuntio ja Kirkkonummiga. See vôib, ent ei pruugi osutada, et ka Olef Molner oli pärit Uusimaalt. Asjaolu, et Michel Sittow valmistas millalgi enne i515. aastat Siuntio kiriku jaoks skulptuure, ei tõesta tema vanaisa pärinemist sealt kandist (ehkki môistagi ka ei välista seda). Kokkuvôtvalt vôib tốdeda, et ehkki Johanseni väiteid tuleb nii môneski küsimuses korrigeerida, on Olef Molneri side Soomega siiski tôestatud.

Molnerite suguvốsa on Tallinnas jälgitav mitme pôlvkonna vältel: Olef Molner vanema kaubandustegevust jätkasid tema poeg Olef ja pojapoeg Hans. Elukutse üleminek isalt pojale oli tolleaegses ühiskonnas sagedane.

Lốuna-Soomest, eriti Uusimaa maakonnast on keskaegsesse Tallinna saabunud küllaltki arvukalt elanikke, mistõttu kahe maa vaheliste kaubanduslike ja suhtevốrgustike lähem uurimine, kaasates nii Soome kui ka Eesti allikaid, on ühtaegu oluline ja perspektiivikas. 